\section{JURNAL EKONOMI EFEKTIF}

ISSN : $2622-8882$, E-ISSN : 2622-9935

Jurnal Ekonomi Efektif, Vol. 2, No. 3, April 2020

@Prodi Manajemen Fakultas Ekonomi Universitas

Pamulang

\title{
PENGARUH KOMUNIKASI DAN DISIPLIN KERJA TERHADAP KINERJA GURU PADA SMK ISLAMIYAH CIPUTAT
}

\author{
Dian Rostikawati ${ }^{1 *}$, H. San Ridwan Maulana ${ }^{2}$ \\ Universitas Pamulang \\ drostikawati@gmail.com*
}

\begin{abstract}
ABSTRAK
Penelitian ini bertujuan untuk mengetahui pengaruh komunikasi dan disiplin kerja terhadap kinerja guru pada SMK Islamiyah Ciputat. Metode yang digunakan adalah explanatory research dengan teknik analisis menggunakan analisis statistik dengan pengujian regresi, korelasi, determinasi dan uji hipotesis. Hasil penelitian ini komunikasi berpengaruh signifikan terhadap kinerja guru sebesar 45,1\%, uji hipotesis diperoleh $\mathrm{t}$ hitung $>\mathrm{t}$ tabel atau $(6,776>2,003)$. Disiplin kerja berpengaruh signifikan terhadap kinerja guru sebesar $63,0 \%$, uji hipotesis diperoleh $t$ hitung $>\mathrm{t}$ tabel atau $(9,775>2,003)$. Komunikasi dan disiplin kerja secara simultan berpengaruh signifikan terhadap kinerja guru dengan persamaan regresi $\mathrm{Y}=$ $5,787+0,309 \mathrm{X} 1+0,556 \mathrm{X} 2$ dan kontribusi pengaruh sebesar 71,0\%, uji hipotesis diperoleh $\mathrm{F}$ hitung $>\mathrm{F}$ tabel atau $(67,166>2,770)$.
\end{abstract}

\section{Kata Kunci: Komunikasi, Disiplin Kerja, Kinerja Guru.}

\begin{abstract}
This study aims to determine the effect of communication and work discipline on teacher performance in Ciputat Islamic Vocational School. The method used is explanatory research with analytical techniques using statistical analysis with regression testing, correlation, determination and hypothesis testing. The results of this study have a significant effect on communication teacher performance by $45.1 \%$, the hypothesis test obtained t count> t table or (6.776> 2.003). Work discipline has a significant effect on teacher performance of $63.0 \%$, the hypothesis test is obtained t arithmetic $>t$ table or $(9,775>2,003)$. Communication and work discipline simultaneously have a significant effect on teacher performance with a regression equation $Y=5.787+0.309 X 1+0.556 X 2$ and the contribution of influence is $71.0 \%$, the hypothesis test is obtained F count $>F$ table or $(67.166>2.770)$.
\end{abstract}

Keywords: Communication, Work Discipline, Teacher Performance 


\section{PENDAHULUAN}

\section{A. Latar Belakang Masalah}

Secara umum pengertian manajemen adalah ilmu dan seni perencanaan, pengorganisasian, pengarahan dan pengawasan terhadap usaha-usaha para anggota organisasi dan pengunaan sumber daya organisasi untuk mencapai tujuan yang telah di tetapkan sebelumnya. Manajemen memiliki kegiatan memimpin, mengatur, mengelola, mengendalikan, dan mengembangkan.

Manajemen dapat dikatakan sebagai seni. Manajemen merupakan seni dalam menyelesaikan pekerjaan melalui kerja sama dengan orang lain. Seni manajemen terdiri dari kemampuan untuk melihat totalitas di bagian-bagian yang terpisah dari suatu kesatuan gambaran tentang visi. Seni manajemen mencakup kemampuan komunikasi visi tersebut. Aspek-aspek perencanaan kepemimpinan, komunikasi dan pengambilan keputusan mengenai unsur manusia tentang cara menggunakan pendekatan manajemen seni. Suatu negara pasti mempunyai dan membutuhkan sumber daya manusia untuk memenuhi tujuan yang ingin dicapai oleh negara tersebut, misalnya dalam bidang ekonomi, sosial, pendidikan, dan sebagainya. Sumber daya manusia ini harus dikelola dengan baik agar bakat dan kemampuannya dapat bermanfaat secara utuh, maksimal, dan tepat sasaran melalui metode-metode dan sistem yang efektif dan efisien.

Sumber daya manusia terdiri dari dua hal, yaitu daya fisik dan daya pikir yang nantinya akan menentukan kemampuan manusia. Dalam suatu aktivitas, anusia adalah unsur utamanya, tidak peduli meskipun banyak peralatan canggih yang sudah bisa bekerja secara instan, namun peralatan tersebut tidak akan bisa berfungsi jika tidak dikelola oleh manusia. Sumber daya manusia dimaknai sebagai salah satu faktor penting bagi sebuah perusahaan selain faktor modal. Faktor sumber daya manusia ini dianggap penting karena membutuhkan pengelolaan yang baik dalam rangka peningkatan mutu organisasi maupun perusahaan.

Jadi pengertian singkat mengenai manajemen sumber daya manusia itu adalah suatu proses yang terdiri atas perencanaan, pengorganisasian, pemimpin dan pengendalian kegiatan-kegiatan yang berkaitan dengan analisis pekerjaan, evaluasi pekerjaan, pengadaan, pengembangan, kompensasi, promosi, dan pemutusan hubungan kerja guna mencapai tujuan yang ditetapkan.

Sumber daya manusia memliki peranan penting di dalam badan organisasi, terutama untuk mencapai tujuan suatu organisasi, didalam bidang pendidikan peran guru lah yang sangat penting, bagaimana para guru bisa memenuhi kebutuhan para siswa nya, sehingga membantu sekolah mencapai tujuan sekolah tersebut. Salah satu permalasalahan yang paling mendasar yang sedang di hadapi oleh bangsa Indonesia adalah rendah nya mutu pendidikan pada setiap jenjang dan satuan pendidikan dasar dan menengah, berbagai usaha telah di lakukan oleh pemerintah untuk meningkat kan mutu pendidikan nasional, antara lain melalui berbagai pelatihan terhadap guru guna meningkat kualitas guru yang ada di Indonesia, pengadaan buku, peningkatan sarana dan prasarana sekolah serta perbaikan di bidang manajement sekola Salah satu cara yang dapat di lakukan guru-guru SMK Islamiyah Ciputat untuk melakukan pendekatan terhadap siswa nya adalah dengan cara berkomunikasi dengan baik. Komunikasi sangat penting bagi kita sebagai mahluk sosial, karena komunikasi adalah salah satu cara kita untuk berinteraksi satu sama lain. Komunikasi pun ada beberapa macam nya, ada komunikasi secara lisan dan ada juga komunikasi secara tertulis. Komunikasi secara lisan adalah komunikasi secara langsung, bisa juga dengan tatap muka maupun dengan menggunakan media elektronik seperti telpon genggam, sedangkan komunikasi secara tertulis biasanya berbentu surat, naskah dan blangko. 
Komunikasi juga ada bentuk nya, yaitu komunikasi horizontal yang bentuk mendatar bisa dikatakan komunikasi yang se-level atau sesame jabatan, lalu ada juga komunikasi vertical, yaitu komunikasi dari atasan yang turun ke bawahan.

Komunikasi sangat lah berguna untuk di dunia kerja maupun untuk di dunia belajar mengajar. Terutama dalam bidang pendidikan, apa bila terjadi komunikasi yang baik antara guru dengan siswa, maka siswa tersebut akan sangat mudah memahami pelajaran yang mereka terima. Dalam dunia kerjapun tidak kalah penting nya, komunikasi yang baik akan memudahkan perusahaan tersebut untuk mencapai visi dan misi yang sudah di tetapkan oleh perusahaan.

Dalam dunia nyata keberhasilan seorang guru untuk mendidik para siswa nya harus di mulai dengan komunikasi yang baik, supaya para siswa dapat memahami ilmu yang di berikan oleh guru nya dengan baik. Komunikasi yang terjalin di dalam sekolah tidak hanya antara para guru dan murid, namun kesuksesan komunikasi didalam sekolah juga di mulai dari hubungan yang baik antara kepala sekolah terhadap para guru, maupun komunikasi yang terjalin sesama guru. Menurut Keith Davis dalam Anwar Prabu Mangkunegara 2013:145) mengatakan, komunikasi adalah pemindahan informasi dan pemahaman dari seseorang kepada orang lain. Sayang nya komunikasi yang terjalin di antara sesama guru masih kurang baik, sehingga guru masih kurang baik, sehingga cukup sulit untuk mencapai visi dan misi yang di miliki sekolah.

Tidak hanya dalam komunikasi, guru pun harus memberikan contoh disiplin terhadap para siswa nya, kebanyakan siswa jaman sekarang tidak memiliki jiwa disiplin, maka dari itu peran guru pun sangat penting untuk membentuk kararter siswa itu sendiri, mungkin dengan cara disiplin kerja. Guru guru pun mampu mengajarkan disiplin kepada siswa nya melalui ke giatan sehari hari, contoh nya iyalah datang tepat waktu saat jam pelajaran di mulai, dan memberikan hukuman kepada siswa nya yang datang terlambat, sehingga siswa tersebut memiliki sisi jera untuk mengulangi nya kembali, dan di situ lah sifat disiplin siswa mulai terbentuk.

Menurut Rivai (2011: 825) bahwa disiplin kerja merupakan suatu alat yang di pergunakan oleh manager untuk. berkomunikasi kepada karyawan supaya mereka siap merubah suatu perilaku serta sebagai sebuah upaya untuk meningkatkan kesadaran dan kesidiaan seseorang untuk memenuhi segala peraturan perusahaan. Disini guru yang berperan sebagai tenaga pendidik harus memberikan contoh positif kepada para siswa nya, sehingga siswa pun termotifasi untuk meningkatkan kesadaran nya dan mampu mentaati peraturan yang di terapkan oleh SMK Islamiyah Ciputat.

Faktor yang mempengaruhi bagus atau tidak nya nilai siswa adalah kinerja guru nya tersebut, apa bila kinerja guru tersebut telah maksimal akan berpengaruh kepada nilai siswa nya pula, peran guru pun sangat berpengaruh epada tingkat perkembangan siswa nya baik secara akademik mau pun non akademik. Kinerja guru menurut Supardi (2014:54) merupakan kemampuan seorang guru dalam melaksanakan tugas pembelajaran di sekolah dan ber tanggung jawab atas peserta didik di bawah bimbingannya dengan meningkatkan prestasi peserta didik nya. Jadi tugas guru sebagai tenaga pendidik harus dapat menyampaikan ilmu dan materi pembelajaran kepada para siswa nya, hasil ang harus di capai oleh guru sebagai tenaga pendidik adalah meningkat nya nilai para siswa dari tahun ke tahun, namun apa bila guru yang berperan sebagai tenaga pendidik masih tidak memiliki rasa di siplin yang tinggi, bagai mana siswa akan terbentuk nya karakter yang baik. 


\section{B. Perumusan Permasalahan Penelitian}

1. Adakah pengaruh secara parsial antara komunikasi terhadap kinerja guru pada SMK Islamiyah Ciputat?.

2. Adakah pengaruh secara parsial antara disiplin kerja terhadap kinerja guru pada SMK Islamiyah Ciputat?.

3. Adakah pengaruh secara simultan antara komunikasi dan disiplin kerja terhadap kinerja guru pada SMK Islamiyah Ciputat?

\section{Manfaat Penelitian}

1. Untuk mengetahui pengaruh secara parsial antara komunikasi terhadap kinerja guru pada SMK Islamiyah Ciputat.

2. Untuk mengetahui pengaruh secara parsial antara disiplin kerja terhadap kinerja guru pada SMK Islamiyah Ciputat.

3. Untuk mengetahui pengaruh secara simultan antara komunikasi dan disiplin kerja terhadap kinerja guru pada SMK Islamiyah Ciputat.

\section{METODE PENELITIAN}

Populasi dalam penelitian ini berjumlah 58 responden guru SMK Islamiyah Ciputat. Teknik pengambilan sampling dalam penelitian ini adalah samplel jenuh, dimana semua anggota populasi dijasikan sebagai sampel. Dengan demikian sampel dalam penelitian ini berjumlah 58 responden. Jenis penelitian yang dipakai adalah asosiatif, dimana tujuannya adalah untuk mengetahui pengaruh antara variabel bebas terhadap variabel terikat baik parsial maupun simultan. Dalam menganalisis data digunakan uji instrumen, uji asumsi klasik, regresi, koefisien determinasi dan uji hipotesis

\section{HASIL PENELITIAN DAN PEMBAHASAN}

\section{A. Hasil Penelitian}

\section{Karakteristik Responden}

Pada pengujian ini digunakan untuk mengetahui skor minimum dan maksimum, mean score dan standar deviasi dari masing-masing variabel. Adapun hasilnya sebagai berikut:

Tabel 1. Hasil Analisis Descriptive Statistics

\section{Descriptive Statistics}

\begin{tabular}{|l|r|r|r|r|r} 
& N & Minimum & Maximum & Mean & Std. Deviation \\
\hline Komunikasi (X1) & 58 & 31 & 47 & 38.03 & 3.834 \\
\hline Disiplin kerja (X2) & 58 & 29 & 48 & 38.59 & 3.862 \\
\hline Kinerja Guru (Y) & 58 & 31 & 47 & 39.00 & 3.524 \\
\hline Valid N (listwise) & 58 & & & & \\
\hline
\end{tabular}

Komunikasi diperoleh varians minimum sebesar 31 dan varians maximum 47 dengan mean score sebesar 3,81 dengan standar deviasi 3,834.

Disiplin kerja diperoleh varians minimum sebesar 29 dan varians maximum 48 dengan mean score sebesar 3,85 dengan standar deviasi 3,862.

Kinerja guru diperoleh varians minimum sebesar 31 dan varians maximum 47 dengan mean score sebesar 3,90 dengan standar deviasi 3,524

\section{Analisis Verifikatif.}

Pada analisis ini dimaksudkan untuk mengetahui pengaruh variabel independen terhadap variabel dependen. Adapun hasil pengujian sebagai berikut: 


\section{a. Analisis Regresi Linier Sederhana dan Berganda}

Uji regresi ini dimaksudkan untuk mengetahui perubahan variabel dependen jika variabel independen mengalami perubahan. Adapun hasil pengujiannya sebagai berikut:

Tabel 2. Hasil Uji Regresi Linier Sederhana Variabel Komunikasi (X1) Coefficients $^{\mathrm{a}}$

\begin{tabular}{|c|c|c|c|c|c|c|}
\hline \multirow{2}{*}{\multicolumn{2}{|c|}{ Model }} & \multicolumn{2}{|c|}{$\begin{array}{l}\text { Unstandardized } \\
\text { Coefficients }\end{array}$} & \multirow{2}{*}{$\begin{array}{c}\text { Standardized } \\
\text { Coefficients } \\
\text { Beta } \\
\end{array}$} & \multirow[b]{2}{*}{$\mathrm{t}$} & \multirow[b]{2}{*}{ Sig. } \\
\hline & & B & Std. Error & & & \\
\hline$\overline{1}$ & (Constant) & 15.533 & 3.480 & & 4.463 & .000 \\
\hline & Komunikasi (X1) & .617 & .091 & .671 & 6.776 & .000 \\
\hline
\end{tabular}

a. Dependent Variable: Kinerja Guru $(\mathrm{Y})$

Berdasarkan hasil pengujian pada tabel di atas, diperoleh persamaan regresi $\mathrm{Y}=$ $15,533+0,617 X 1$. Dari persamaan tersebut dijelaskan sebagai berikut:

1) Konstanta sebesar 15,533 diartikan jika komunikasi tidak ada, sementara variabel lain konstan, maka telah terdapat nilai kinerja guru sebesar 15,533 point.

2) Koefisien regresi komunikasi sebesar 0,617 , angka ini positif artinya setiap ada peningkatan komunikasi sebesar 0,617 maka kinerja guru juga akan mengalami peningkatan sebesar 0,617 point

Tabel 3. Hasil Uji Regresi Linier Sederhana Variabel Disiplin kerja (X2)

$$
\text { Coefficients }^{\mathrm{a}}
$$

Unstandardized

Coefficients

\begin{tabular}{|c|c|c|c|c|c|}
\hline \multirow[b]{2}{*}{ Mod } & \multicolumn{2}{|l|}{ Co } & \multirow{2}{*}{$\begin{array}{l}\text { efficients } \\
\text { Beta }\end{array}$} & \multirow[b]{2}{*}{$\mathrm{t}$} & \multirow[b]{2}{*}{ Sig. } \\
\hline & B & Std. Error & & & \\
\hline $\begin{array}{ll}1 & \text { (Constant) }\end{array}$ & 11.039 & 2.875 & & 3.840 & .000 \\
\hline Disiplin kerja (X2) & .725 & .074 & .794 & 9.775 & .000 \\
\hline
\end{tabular}

a. Dependent Variable: Kinerja Guru $(\mathrm{Y})$

Berdasarkan hasil pengujian pada tabel di atas, diperoleh persamaan regresi $\mathrm{Y}=$ $11,039+0,725$ X2 . Dari persamaan tersebut dijelaskan sebagai berikut:

1) Konstanta sebesar 11,039 diartikan jika disiplin kerja tidak ada, sementara variabel lain konstan, maka telah terdapat nilai kinerja guru sebesar 11,039 point.

2) Koefisien regresi disiplin kerja sebesar 0,725 , angka ini positif artinya setiap ada peningkatan disiplin kerja sebesar 0,725 maka kinerja guru juga akan mengalami peningkatan sebesar 0,725 point

\begin{tabular}{|c|c|c|c|c|c|}
\hline \multirow[b]{2}{*}{ Model } & \multicolumn{2}{|c|}{$\begin{array}{l}\text { Coefficients }^{\mathbf{a}} \\
\text { Unstandardized } \\
\text { Coefficients }\end{array}$} & \multirow{2}{*}{$\begin{array}{c}\text { Standardized } \\
\text { Coefficients } \\
\text { Beta }\end{array}$} & \multirow[b]{2}{*}{$\mathrm{t}$} & \multirow[b]{2}{*}{ Sig. } \\
\hline & $\mathrm{B}$ & Std. Error & & & \\
\hline 1 (Constant) & 5.787 & 2.908 & & 1.990 & .052 \\
\hline Komunikasi (X1) & .309 & .080 & .336 & 3.868 & .000 \\
\hline Disiplin kerja (X2) & .556 & .079 & .609 & 7.002 & .000 \\
\hline
\end{tabular}

Berdasarkan hasil pengujian pada tabel di atas, diperoleh persamaan regresi $\mathrm{Y}=$ $5,787+0,309 \mathrm{X} 1+0,556 \mathrm{X} 2$. Dari persamaan tersebut dijelaskan sebagai berikut:

1) Konstanta sebesar 5,787 diartikan jika komunikasi dan disiplin kerja tidak ada, maka telah terdapat nilai kinerja guru sebesar 5,787 point

2) Koefisien regresi komunikasi sebesar 0,309, angka ini positif artinya setiap ada peningkatan komunikasi sebesar 0,309 maka kinerja guru juga akan mengalami peningkatan sebesar 0,309 point 
3) Koefisien regresi disiplin kerja sebesar 0,556, angka ini positif artinya setiap ada peningkatan disiplin kerja sebesar 0,556 maka kinerja guru juga akan mengalami peningkatan sebesar 0,556 point.

\section{b. Analisis Koefisien Korelasi}

Analisis koefisien korelasi dimaksudkan untuk mengetahui tingkt kekuatan hubungan dari variabel independen terhadap variabel dependen baik secara parsial maupun simultan. Adapun hasil pengujian sebagai berikut:

Tabel 5. Hasil Uji Koefisien Korelasi Komunikasi Terhadap Kinerja Guru Correlations $^{\mathrm{b}}$

\begin{tabular}{llr|r} 
& & $\begin{array}{c}\text { Komunikasi } \\
(\mathrm{X} 1)\end{array}$ & \multicolumn{1}{c}{ Kinerja Guru (Y) } \\
\hline Komunikasi (X1) & Pearson Correlation & 1 & $.671^{* *}$ \\
\cline { 2 - 4 } & Sig. (2-tailed) & & .000 \\
\hline Kinerja Guru (Y) & Pearson Correlation & $.671^{* *}$ & 1 \\
\cline { 2 - 4 } & Sig. (2-tailed) & .000 & \\
\hline
\end{tabular}

${ }^{* \star}$. Correlation is significant at the 0.01 level (2-tailed).

b. Listwise $\mathrm{N}=86$

Berdasarkan hasil pengujian diperoleh nilai korelasi sebesar 0,671 artinya komunikasi memiliki hubungan yang kuat terhadap kinerja guru.

Tabel 6. Hasil Uji Koefisien Korelasi Disiplin kerja Terhadap Kinerja Guru Correlations $^{\mathrm{b}}$

\begin{tabular}{llr|r} 
& & $\begin{array}{c}\text { Disiplin kerja } \\
(\mathrm{X} 2)\end{array}$ & Kinerja Guru (Y) \\
\hline Disiplin kerja (X2) & Pearson Correlation & 1 & $.794^{* *}$ \\
\cline { 2 - 4 } & Sig. (2-tailed) & $.794^{\star *}$ & .000 \\
\hline Kinerja Guru (Y) & Pearson Correlation & .000 & 1 \\
\cline { 2 - 4 } & Sig. (2-tailed) &
\end{tabular}

${ }^{* *}$. Correlation is significant at the 0.01 level (2-tailed).

b. Listwise $\mathrm{N}=86$

Berdasarkan hasil pengujian diperoleh nilai korelasi sebesar 0,794 artinya disiplin kerja memiliki hubungan yang kuat terhadap kinerja guru.

Tabel 7. Hasil Uji Koefisien Korelasi Komunikasi dan Disiplin kerja secara simultan Terhadap Kinerja Guru.

\section{Model Summary}

\begin{tabular}{lrr|rr|r} 
Model & $\mathrm{R}$ & \multicolumn{2}{c|}{$\begin{array}{c}\text { Adjusted R } \\
\text { Square }\end{array}$} & \multicolumn{2}{c}{$\begin{array}{c}\text { Std. Error of the } \\
\text { Estimate }\end{array}$} \\
\hline 1 & & R Square & .710 & .699 & 1.934 \\
\hline
\end{tabular}

a. Predictors: (Constant), Disiplin kerja (X2), Komunikasi (X1)

Berdasarkan hasil pengujian diperoleh nilai korelasi sebesar 0,842 artinya komunikasi dan disiplin kerja secara simultan memiliki hubungan yang sangat kuat terhadap kinerja guru.

\section{c. Analisis Koefisien Determinasi}

Analisis koefisien determinasi dimaksudkan untuk mengetahui besarnya persentase pengaruh dari variabel independen terhadap variabel dependen baik secara parsial maupun simultan. Adapun hasil pengujian sebagai berikut:

Tabel 8. Hasil Uji Koefisien Determinasi Komunikasi Terhadap Kinerja Guru: Model Summary

\begin{tabular}{|c|c|c|c|c|}
\hline Model & $\mathrm{R}$ & R Square & $\begin{array}{l}\text { Adjusted R } \\
\text { Square }\end{array}$ & $\begin{array}{l}\text { Std. Error of the } \\
\text { Estimate }\end{array}$ \\
\hline 1 & $.671^{a}$ & .451 & .441 & 2.636 \\
\hline
\end{tabular}

Berdasarkan hasil pengujian diperoleh nilai determinasi sebesar 0,451 artinya komunikasi memiliki kontribusi pengaruh sebesar $45,1 \%$ terhadap kinerja guru. 
Tabel 9. Hasil Pengujian Koefisien Determinasi Disiplin kerja Terhadap Kinerja Guru. Model Summary

\begin{tabular}{|c|c|c|c|c|}
\hline \multicolumn{5}{|c|}{ Model Summary } \\
\hline Model & $\mathrm{R}$ & R Square & $\begin{array}{l}\text { Adjusted R } \\
\text { Square }\end{array}$ & $\begin{array}{l}\text { Std. Error of the } \\
\text { Estimate }\end{array}$ \\
\hline 1 & $.794^{a}$ & .630 & .624 & 2.161 \\
\hline
\end{tabular}

Berdasarkan hasil pengujian diperoleh nilai determinasi sebesar 0,630 artinya disiplin kerja memiliki kontribusi pengaruh sebesar $63,0 \%$ terhadap kinerja guru.

Tabel 10. Hasil Uji Koefisien Determinasi Komunikasi dan Disiplin kerja Terhadap Kinerja Guru.

Model Summary

\begin{tabular}{|c|c|c|c|c|}
\hline \multicolumn{5}{|c|}{ 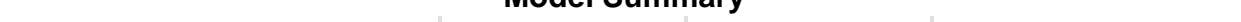 } \\
\hline Model & $\mathrm{R}$ & R Square & $\begin{array}{l}\text { Adjusted R } \\
\text { Square }\end{array}$ & $\begin{array}{l}\text { Std. Error of the } \\
\text { Estimate }\end{array}$ \\
\hline 1 & $.842^{a}$ & .710 & .699 & 1.934 \\
\hline
\end{tabular}

Berdasarkan hasil pengujian diperoleh nilai determinasi sebesar 0,710 artinya komunikasi dan disiplin kerja secara simultan memiliki kontribusi pengaruh sebesar 71,0\% terhadap kinerja guru, sedangkan sisanya sebesar $29,0 \%$ dipengaruhi faktor lain.

\section{Uji Hipotesis}

\section{a. Uji hipotesis Parsial (Uji t)}

Pengujian hipotesis dengan uji t digunakan untuk mengetahui hipotesis parsial mana yang diterima. Hipotesis pertama: Terdapat pengaruh yang signifikan antara komunikasi terhadap kinerja guru.

Tabel 11. Hasil Uji Hipotesis Komunikasi Terhadap Kinerja Guru.

\begin{tabular}{lr|r|r|r|r} 
& \multicolumn{2}{c}{$\begin{array}{c}\text { Unstandardized } \\
\text { Coefficients }\end{array}$} & $\begin{array}{c}\text { Standardized } \\
\text { Coefficients }\end{array}$ & & \\
Model & $\mathrm{B}$ & Std. Error & Beta & $\mathrm{t}$ & \multicolumn{1}{c}{ Sig. } \\
\hline 1 (Constant) & 15.533 & 3.480 & & 4.463 & .000 \\
\hline Komunikasi (X1) & .617 & .091 & .671 & 6.776 & .000 \\
\hline
\end{tabular}

a. Dependent Variable: Kinerja Guru (Y)

Berdasarkan hasil pengujian pada tabel di atas, diperoleh nilai t hitung $>\mathrm{t}$ tabel atau $(6,776>2,003)$, dengan demikian hipotesis pertama yang diajukan bahwa terdapat pengaruh yang signifikan atara komunikasi terhadap kinerja guru diterima.

Tabel 12. Hasil Uji Hipotesis Disiplin kerja Terhadap Kinerja Guru.

\begin{tabular}{|c|c|c|c|c|c|}
\hline \multirow[b]{2}{*}{ Model } & $\begin{array}{r}\text { Unstal } \\
\text { Coe }\end{array}$ & $\begin{array}{l}\text { Coefficients } \\
\text { dardized } \\
\text { ficients }\end{array}$ & $\begin{array}{l}\text { Standardized } \\
\text { Coefficients }\end{array}$ & \multirow[b]{2}{*}{$\mathrm{t}$} & \multirow[b]{2}{*}{ Sig. } \\
\hline & $\mathrm{B}$ & Std. Error & Beta & & \\
\hline 1 (Constant) & 11.039 & 2.875 & & 3.840 & .000 \\
\hline Disiplin kerja (X2) & .725 & .074 & .794 & 9.775 & .000 \\
\hline
\end{tabular}

a. Dependent Variable: Kinerja Guru (Y)

Berdasarkan hasil pengujian pada tabel di atas, diperoleh nilai $\mathrm{t}$ hitung $>\mathrm{t}$ tabel atau $(9,775>2,003)$, dengan demikian hipotesis kedua yang diajukan bahwa terdapat pengaruh yang signifikan atara disiplin kerja terhadap kinerja guru diterima. 


\section{b. Uji Hipotesis Simultan (Uji F)}

Pengujian hipotesis dengan uji $\mathrm{F}$ digunakan untuk mengetahui hipotesis simultan yang mana yang diterima. Hipotesis ketiga Terdapat pengaruh yang signifikan antara komunikasi dan disiplin kerja terhadap kinerja guru.

Tabel 13. Hasil Uji Hipotesis Komunikasi dan Disiplin kerja Terhadap Kinerja

$$
\text { Guru. }
$$

ANOVA $^{\mathrm{a}}$

\begin{tabular}{|c|c|c|c|c|c|c|}
\hline \multicolumn{2}{|c|}{ Model } & Sum of Squares & df & Mean Square & $\mathrm{F}$ & Sig. \\
\hline \multirow[t]{3}{*}{1} & Regression & 502.330 & 2 & 251.165 & 67.166 & $.000^{\mathrm{b}}$ \\
\hline & Residual & 205.670 & 55 & 3.739 & & \\
\hline & Total & 708.000 & 57 & & & \\
\hline
\end{tabular}

Berdasarkan hasil pengujian pada tabel di atas, diperoleh nilai $\mathrm{F}$ hitung $>\mathrm{F}$ tabel atau $(67,166>2,770)$, dengan demikian hipotesis ketiga yang diajukan bahwa terdapat pengaruh yang signifikan atara komunikasi dan disiplin kerja terhadap kinerja guru diterima.

\section{B. Pembahasan}

\section{Pengaruh Komunikasi Terhadap Kinerja Guru}

Komunikasi berpengaruh signifikan terhadap kinerja guru dengan diperoleh persamaan regresi $\mathrm{Y}=15,533+0,617 \mathrm{X} 1$, nilai korelasi sebesar 0,671 atau memiliki hubungan yang kuat dengan kontribusi pengaruh sebesar $45,1 \%$. Pengujian hipotesis diperoleh nilai $\mathrm{t}$ hitung $>\mathrm{t}$ tabel atau $(6,776>2,003)$. Dengan demikian hipotesis pertama yang diajukan bahwa terdapat berpengaruh signifikan antara komunikasi terhadap kinerja guru diterima.

\section{Pengaruh Disiplin kerja Terhadap Kinerja Guru}

Disiplin kerja berpengaruh signifikan terhadap kinerja guru dengan diperoleh persamaan regresi $\mathrm{Y}=11,039+0,725 \mathrm{X} 2$, nilai korelasi sebesar 0,794 atau memiliki hubungan yang kuat dengan kontribusi pengaruh sebesar 63,0\%. Pengujian hipotesis diperoleh nilai t hitung $>\mathrm{t}$ tabel atau $(9,775>2,003)$. Dengan demikian hipotesis kedua yang diajukan bahwa terdapat berpengaruh signifikan antara disiplin kerja terhadap kinerja guru diterima.

\section{Pengaruh Komunikasi dan Disiplin kerja Terhadap Kinerja Guru}

Komunikasi dan disiplin kerja berpengaruh signifikan terhadap kinerja guru dengan diperoleh persamaan regresi $\mathrm{Y}=5,787+0,309 \mathrm{X} 1+0,556 \mathrm{X} 2$, nilai korelasi sebesar 0,842 atau memiliki hubungan yang kuat dengan kontribusi pengaruh sebesar $71,0 \%$ sedangkan sisanya sebesar 29,0\% dipengaruhi faktor lain. Pengujian hipotesis diperoleh nilai F hitung > F tabel atau $(67,166>2,770)$. Dengan demikian hipotesis ketiga yang diajukan bahwa terdapat berpengaruh signifikan antara komunikasi dan disiplin kerja terhadap kinerja guru diterima.

\section{PENUTUP}

\section{A. Kesimpulan}

1. Komunikasi berpengaruh signifikan terhadap kinerja guru dengan kontribusi pengaruh sebesar $45,1 \%$. Uji hipotesis diperoleh nilai $t$ hitung $>\mathrm{t}$ tabel atau $(6,776>$ 2,003).

2. Disiplin kerja berpengaruh signifikan terhadap kinerja guru dengan kontribusi pengaruh sebesar $63,0 \%$. Uji hipotesis diperoleh nilai t hitung $>\mathrm{t}$ tabel atau $(9,775>$ $2,003)$. 
3. Komunikasi dan disiplin kerja berpengaruh signifikan terhadap kinerja guru dengan kontribusi pengaruh sebesar $71,0 \%$ sedangkan sisanya sebesar $29,0 \%$ dipengaruhi faktor lain. Uji hipotesis diperoleh nilai $\mathrm{F}$ hitung > F tabel atau $(67,166>2,770)$.

\section{B. Saran}

Komunikasi pernyataan yang paling lemah adalah nomor 10 yaitu seluruh jajaran mampu mentaati apa yang menjadi kebijakan yayasan, dimana hanya mencapai rata-rata score sebesar 3,57. Untuk lebih baik lagi yayasan harus secara intens menyampaikan dengan jelas apa yang menjadi arah dan kebijakan yayasan

Komunikasi kerja pernyataan yang paling lemah adalah nomor 1 yaitu Guru memiliki kepedulian yang baik pada yayasan, dimana hanya mencapai rata-rata score sebesar 3,64. Untuk lebih baik lagi yayasan harus secara tegas memberikan penekanan pada integritas guru dalam melaksanakan tugas dan kewajibannya

Kinerja guru pernyataan yang paling lemah adalah nomor 1 yaitu Guru memiliki kemampuan dalam menyelesaikan jumlah pekerjaan dengan baik, dimana hanya mencapai rata-rata score sebesar 3,71. Untuk lebih baik lagi yayasan harus melakukan pelatihan-pelatihan yang sifatnya menambah kemampuan dan pengetahuan pada guru.

\section{DAFTAR PUSTAKA}

Algifari (2015). Analisis Regresi untuk Bisnis dan Ekonomi. Yogyakarta: BPFE.

Handoko T. Hani, 2008, Manajemen Personalia dan Sumber Daya Manusia, edisi kedua, Penerbit : BPFE, Yogyakarta.

Imam Ghozali (2017). Aplikasi Analisis Multivariate Dengan Program SPSS. Edisi Kelima. Semarang: Badan Penerbit Undip. Indonesia, Jakarta.

Lukiastuti, Fitri, et.al (2020). The Influence of Entrepreneur's Personal Characteristics on SMES Performance Mediated by Entrepreneurial Orientation. International Journal of Psychosocial Rehabilitation. Volume 24 - Issue 8

Rozi, A., \& Sunarsi, D. (2020). The Influence of Motivation and Work Experience on Employee Performance at PT. Yamaha Saka Motor in South Tangerang. Jurnal Office, 5(2), 65-74.

Sobarna, A., Hambali, S., Sutiswo, S., \& Sunarsi, D. (2020). The influence learning used $\mathrm{ABC}$ run exercise on the sprint capabilities. Jurnal Konseling dan Pendidikan, 8(2), 67-71.

Sugiyono (2017), Metode Penelitian Administrasi : dilengkapi dengan Metode $R \& D$, Bandung: Alfabeta.

Sunarsi, D. (2018). Buku Ajar: Seminar Perencanaan Sumber Daya Manusia. Tangerang Selatan: Asmoro Mediatama

Sunarsi, D. (2018). Pengembangan Sumber Daya Manusia Strategik \& Karakterisrik Sistem Pendukungnya : Sebuah Tinjauan. Jurnal Ilmiah MEA (Manajemen, Ekonomi, \& Akuntansi), 2(3), 178 - 194.

Sunarsi, D. (2019). Seminar Sumber Daya Manusia. Tangerang Selatan: Unpam Press

Yuangga, K. D., \& Sunarsi, D. (2018). The Influence of Procrastination and Low Time Management on Student Self Efficacy (at MA Soebono Mantofani). PINISI Discretion Review, 2(1), 85-92.

Yuniarsih Tjutju, dan Suwatno, 2008, Manajemen Sumber Daya Manusia, cetakan pertama, Penebit : Alfabeta, Bandung. 